\title{
IDENTIFICATION OF RIVER BANK EROSION AND INUNDATION HAZARD ZONES USING GEOSPATIAL TECHNIQUES - A CASE STUDY OF INDUS RIVER NEAR LAYYAH DISTRICT, PUNJAB, PAKISTAN
}

\author{
H. U. A. Khan ${ }^{\text {a, }}$ S. F. A. Khalil ${ }^{\text {a }}$, S. J. H. Kazmi ${ }^{\text {a }}$, M. Umar ${ }^{\text {a }}$, A. Shahzad ${ }^{\text {a }}$, S. B. Farhan ${ }^{\text {a }}$ \\ a University of Karachi, Pakistan
}

Article Info:

Received: 06 March 2017

in revised form: 24 July 2017

Accepted: 26 July 2017

Available Online: 30 October 2017

\section{Keywords:}

Geospatial, Indus River, river bank erosion, inundation, Layyah District, river morphology.

\section{Corresponding Author:} Hafiz Uzair Ahmad Khan University of Karachi, Pakistan Email:

uzairkhan.geoscientist@hotmail.com

\begin{abstract}
This study aims to assess an area of about $70 \mathrm{~km}$ along Indus River in Layyah and Muzaffargarh districts of Punjab, Pakistan, which is highly vulnerable to erosion. Actual erosion and deposition has been quantified for each of left and right bank of river over a period of 2002 to 2016. Open source data product of Landsat was used to identify the spatio-temporal changes of Indus River. A model has been developed that extracted the water from satellite images using NDWI. River path of Indus has been mapped for 2002, 2009 and 2016 during high and low flow seasons which not only signifies the channel shifting and river morphology, but also highlights the zones where water over run into land. It has been observed from the study that river is shifting more towards its left bank and the area is highly vulnerable to erosion. In 2009, river eroded $24.3 \mathrm{~km}^{2}$ from right bank while it eroded $100 \mathrm{~km}^{2}$ from left bank. Similarly, in 2016, an erosion of $12.5 \mathrm{~km}^{2}$ and $71.9 \mathrm{~km}^{2}$ from right and left bank, respectively, was occurred. The river inundation eroded the major agricultural land and affected the life of people and infrastructure. Results provided the latest and reliable information on the dynamics of Indus River in the study area which can be utilized to develop erosion control program and taking practical measures to ensure the safety of life and infrastructure.
\end{abstract}

Copyright (C) 2017 GJGP-UNDIP This open access article is distributed under Creative Commons Attribution (CC-BY-NC-SA) 4.0 International license.

How to cite (APA 6th Style):

Khan, H. U. A., et al. (2017). Identification of River Bank Erosion and Inundation Hazard Zones Using Geospatial Techniques - A Case Study of Indus River near Layyah District, Punjab, Pakistan. Geoplanning: Journal of Geomatics and Planning, 4(2), 121-130. doi:10.14710/geoplanning.4.2.121-130

\section{INTRODUCTION}

The Indus River system is one of the prime rivers on the Asian region (Clift, 2002). The Indus River serves as the salvation of the country Pakistan. Running from North to South in north-western direction since ages, this river system keeps running for $3,180 \mathrm{~km}$ (Searle \& Owen, 1999). A great part of the Indus River flinches in the hilly sites of the Karakoram and Himalayas. The real tributaries of the River Indus system are River Chenab, River Jhelum, and River Kabul, which causes flooding due to excess of water that flows during monsoon. This river system stands out amongst the most critical systems of the world and the paramount system of Pakistan (Khan, Iqbal, \& Yosufzai, 2011). The Indus keeps on following the strike of the suture before slicing orthogonally through the Himalaya in NW Pakistan and running south to the Arabian Sea (Clift, 2002).

The River bank erosion mostly occurs when the river is flooded or soon after the flood. It is a natural geomorphic process or disturbance that shapes the land. It is fundamental for operating river ecosystems (Florsheim, Mount, \& Chin, 2008). River bank disintegration and its impacts on channel advancement are fundamental geomorphic look into issues with pertinence to numerous logical and designing fields (Sarkar, 2012). To monitor these issues, satellite remote sensing provides frequent synoptic view of an area and comprises comprehensive information about the earth surface. Great number of earth observing satellites orbits around the globe to provide high resolution spatial and temporal data of earth surface. Landsat is among the most widely used satellite, somewhat in light of the fact that it has the longest time series of data in currently available satellites. 
Large number of studies have been conducted in the past related to monitoring of erosion either direct detection or detection of erosion consequences and river bank shifting using remote sensing and Geographic Information System (GIS) (Fuller, Large, \& Milan, 2003; Kotoky et al., 2005; Kummu, Lu, Rasphone, Sarkkula, \& Koponen, 2008; Lawler, 1993; Li, Lu, \& Chen, 2007; Muller, Decamps, \& Dobson, 1993; Pati et al., 2008; Rinaldi, 2003; Sarkar, 2012; Surian, 1999; Thakur, Laha, \& Aggarwal, 2012; Yang, 1996; Yang, Damen, \& van Zuidam, 1999). Lawler (1993) did a review on measurement of the river bank erosion and lateral channel changes. The methods covered by Lawler in this review were historical sources, sedimentological and botanical evidence, repeated cross profiling, planimetric resurvey, erosion pins, and terrestrial photogrammetry. Fuller, Large, and Milan (2003) quantified 3D morphological adjustment in a chute cut-off alluvial channel using digital elevation model (DEM) analysis for about $0.7 \mathrm{~km}$ reach of the River Coquet, Northumberland, UK. The calculations indicate that at least $6,600 \mathrm{~m}^{3}$ of sediment was deposited on emerging bars within the reach over the survey period, and $>2,300 \mathrm{~m}^{3}$ deposited within the channel whereas the sediment losses from the reach may have exceeded $6,500 \mathrm{~m}^{3}$.

Thakur, Laha, and Aggarwal (2012) examined the river bank erosion of Ganga River due to morphometric change. They measured the parameters such as sinuosity, braidedness index, and percentage of the island area to the total river reach area for the years 1955, 1977, 1990, 2001, 2003, and 2005 from LANDSAT and IRS satellite images. They measured the temporal shift for the reach between Farakka and Rajmahal with the help off 22 cross sections and identified that the river is engulfing the left bank.

Pati et al. (2008) studied the river bank erosion of Majuli Island, which is considered to be the world's largest river island located in middle of Brahmaputra River in Assam. They examined the trend of erosion in small stretch of about $11 \mathrm{~km}$ of Majuli Island near Kaniajan Village in south Majuli. They prepared the erosion and deposition map measured at various sections at $1 \mathrm{~km}$ interval using satellite data of 1991, 1997, and 1998. Kotoky et al. (2005) also assessed the nature of river bank erosion along Brahmaputra River. Their study reveals that mechanisms involved and responsible for riverbank erosion were basically related to aqueous flow of sediments (liquefaction) enhanced by the inhomogeneity in the bank materials in question, over steepening and associated sub-aerial processes of weathering and weakening in relation to soil moisture content. Further, Sarkar (2012) carried out the remote sensing and GIS based assessment of Brahmaputra River dynamics in India. They quantified the actual bank erosion/deposition along the river for a period of eighteen years (1990-2008). Yang (1996) and Yang, Damen, and van Zuidam (1999) documented remote sensing and GIS based time-sequential dynamic environmental changes and the analysis of contemporary processes that are involved in the active Yellow River Delta, China. Winterbottom \& Gilvear (2000) used a GIS-based approach for mapping probabilities of river bank erosion in regulated River Tummel, Scotland. Muller, Decamps, and Dobson (1993) in their review summarized the currently available satellite data and its applications in river system studies.

Khan and Ali (2003) studied the effects of erosion on Indus River Bio-diversity. They analyse various physico-chemical parameters including suspended solids, light penetration, total dissolved solids, alkalinity, total volatile solids, dissolved oxygen, electric conductivity, and $\mathrm{pH}$ from Layyah, Taunsa Barrage and Mithan kot. Their study revealed that the area is subjected to immense erosion pressure. Further, spatially distributed erosion and sediment yield modeling in the upper Indus basin has been carried out by Ali \& De Boer (2010).

Considering all the previous studies, we decided to highlight river erosion in a stretch of about $70 \mathrm{~km}$ of Indus River along Layyah and Muzaffargarh Districts, Punjab. In the left bank of the study area, the river is engulfing the land so, there is a need to analyze the whole shifting trend of Indus over spatio-temporal domain. To achieve this aim, the study has been carried out to quantify the amount of channel migration or change on spatial and temporal basis with the help of satellite data which provided the information on the channel configuration of the river system on repetitive basis revealing much needed data on the changes in river morphology, erosion and deposition pattern and its influence on the land, stable and unstable zones of the river banks, changes in the main channel of the Indus River, and overall impact assessment due to river bank erosion. 


\section{DATA AND METHODS}

\subsection{Study Area}

The Indus River, which according to Wolpert (1999) is main artery of Pakistan and Greco-Persians called Indus a "Lion". For centuries, savage Indus surges thundered down Himalayan valleys to cover the deserted tenants of towns and villages raised excessively near its banks. This study identified the Indus River bank shifting along the Layyah District of Punjab which causes the erosion and land degradation. The river inundation causes major agricultural land erosion that directly affects the life of the villagers, raised in the vicinity. For this study, an area of around $70 \mathrm{~km}$ in length along the Layyah and Muzaffargarh Districts on the left bank of Indus River up to the upper stream of Taunsa Barrage was focused (Figure 1). The area lies between $31^{\circ} 4^{\prime} 0.321^{\prime \prime} \mathrm{N}, 70^{\circ} 49^{\prime} 41.066^{\prime \prime} \mathrm{E}$ and $30^{\circ} 31^{\prime} 32.086^{\prime \prime} \mathrm{N}, 70^{\circ} 51^{\prime} 16.301 " \mathrm{E}$ geographic coordinates.

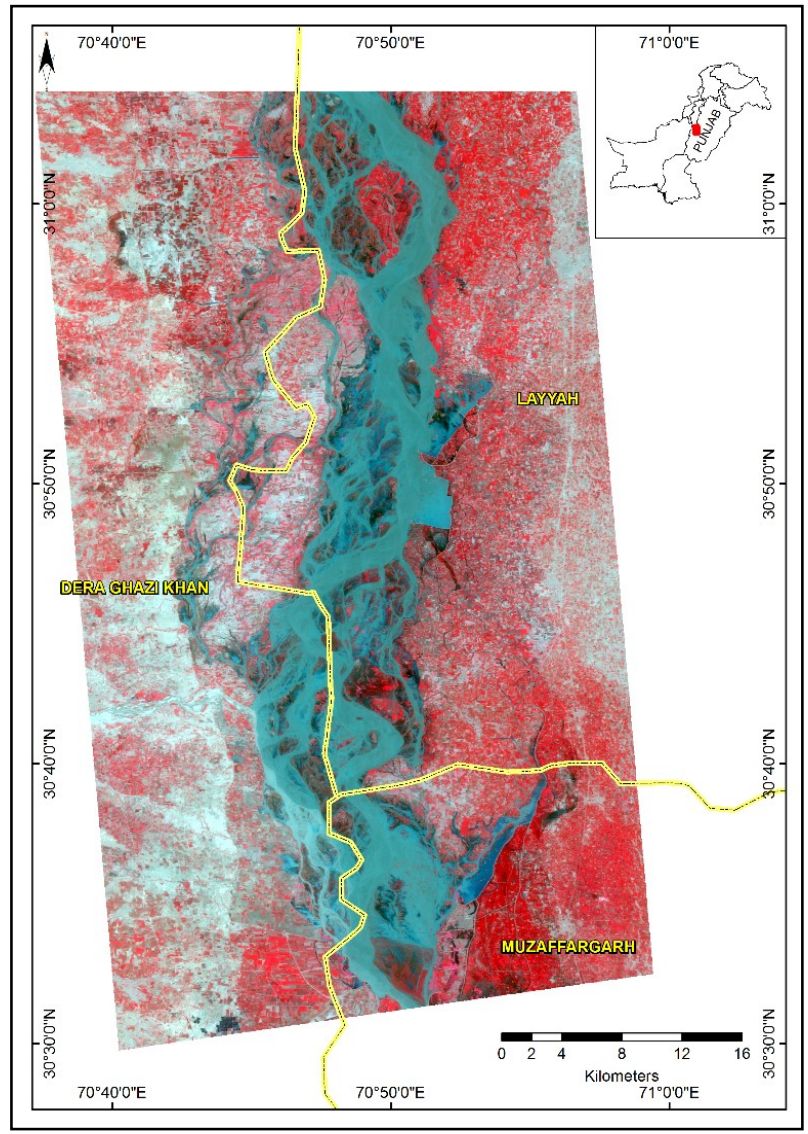

Figure 1. False Colour Composite FCC of study area

\subsection{Data Used}

Multi-temporal satellite images of Landsat (path 150, row 039) for the years 2002, 2009 \& 2016 were used in this study and processed to obtain the prerequisite information (data available from the U.S. Geological Survey). The spatial resolution of Landsat data was $30 \mathrm{~m}$. In the current study we focused on high flow (July, August) and low flow (November, December) seasons. The years were selected after availability of open source Landsat data. Table 1 lists down the important parameters of the data used in the study.

Table 1. Product Information

\begin{tabular}{llll}
\multicolumn{1}{c}{ Satellite \& sensor } & \multicolumn{1}{c}{ Date of Acquisition } & & Season \\
\hline Landsat 7 ETM+ & 29-July-2002 & High Flow & $30 \mathrm{~m}$ \\
\hline Landsat 5 TM & 02-November-2002 & Low Flow & $30 \mathrm{~m}$ \\
\hline Landsat 5 TM & 09-August-2009 & High Flow & $30 \mathrm{~m}$ \\
\hline Landsat 5 TM & 15-December-2009 & Low Flow & $30 \mathrm{~m}$ \\
\hline Landsat 8 OLI+TIRS & 12-August-2016 & High Flow & $30 \mathrm{~m}$ \\
\hline Landsat 8 OLI+TIRS & 31-October-2016 & Low Flow & $30 \mathrm{~m}$
\end{tabular}




\subsection{Methods}

Satellite images for years 2002, 2009 and 2016 have been processed to obtain the required information about the study area. The following section describes detailed preparation of satellite image for extraction of water from these images.

\section{a. Digital Image Processing}

Landsat data acquired from open source available data sets. Landsat Level-1B data is already geometrically corrected and have World Geodetic System (WGS) 1984 datum with spatial reference of Universal Transverse Mercator (UTM) Zone 42 North. Geometric correction is a pre-processing step which is applied to avoid geometric distortions in image. It creates the relationship between assigned coordinates of the image and real world geographic coordinates. For this purpose, it uses measured data of position and attitude, calibration data of the sensor, ground control points, etc. To ensure geo-referencing, we established the relationship between GCP's collected from Google earth and all the Landsat images used in our study. The location of GCPS and check points were identified visually.

\section{b. NDWI layer extraction}

McFeeters (1996) established NDWI (Normalized Difference Water Index) technique which is used to delineate open water features and improve their presence in satellite imagery (Equation [1]). NDWI uses reflected near infrared and visible green light to enhance features of water and eliminating soil and other vegetation features of surface. The following index is used in extraction of water from selected satellite images.

$$
N D W I=\frac{\text { Green }-S W I R}{\text { Green }+ \text { SWIR }}
$$

A model has been developed in ArcGIS that uses the Green and Short Wave Infra-Red (SWIR) bands of Landsat data and extract NDWI image. Then it selected the range of pixel values that represent water in the layer. Selected range was then converted into polygon and refined. The model was run on all six images of high and low flow seasons.

\section{c. River bank delineation}

The entire study area is divided into 10 zones, starting from zone 1 in the north to zone 10 in south, with equal separation of around $7 \mathrm{~km}$. For this purpose, a fishnet from data management toolbox in ArcGIS has been created that provide equal spacing of the study area. This fishnet is used to clip the extracted river shape files of all seasons, into 10 equal parts. The extracted polygon that represented the river path, then analyzed and compared with same season layers of future years. For example, high flow of 2002 has been compared with high flow of 2009 and then high flow of 2009 was compared with high flow of 2016. Similarly, the analysis is conducted on the low flow seasons.

Spatial analyst and geo-processing tools are used readily to figure out the composite changes in the river path (i.e. gradual erosion and deposition). Water layer from model was then extracted, digitally overlaid and compared with other layers. Each layer has been subtracted with preceding year to extract the erosion and with previous year to extract deposition. This estimation empowers precise calculations of the distance to river, eroded or inundated area and deposition zones because of river path changes and flooding during various satellite image acquisitions. Measurement were taken as erosion if river inundates the area, as deposition if river moves away from land leaving fluvial deposits there, and as no change if the river maintain its path during all the years.

\section{RESULTS AND DISCUSSION}

The final river vector maps derived from the model in Figure 2 shows that the river path along the entire Layyah and Muzaffargarh Districts changed significantly during 2002 to 2016. (A), (B), \& (C) shows the river path during high flow seasons while (E), (F) \& (G) shows river path during low flow seasons. It is presumed that the area covered with "water" in historic data showing "land or sediments deposition" in subsequent data is due to the deposition of sediments by the river. Similarly, if historic data was "land" and river water 
actually flows over there, it is due to the erosion. The river eroded as well as deposited sediments in many places throughout the districts. It can be observed from data that erosion and deposition, both were very high along the left bank of river. Resulting deposited areas at many places have been recently developed and are used for agriculture practices.
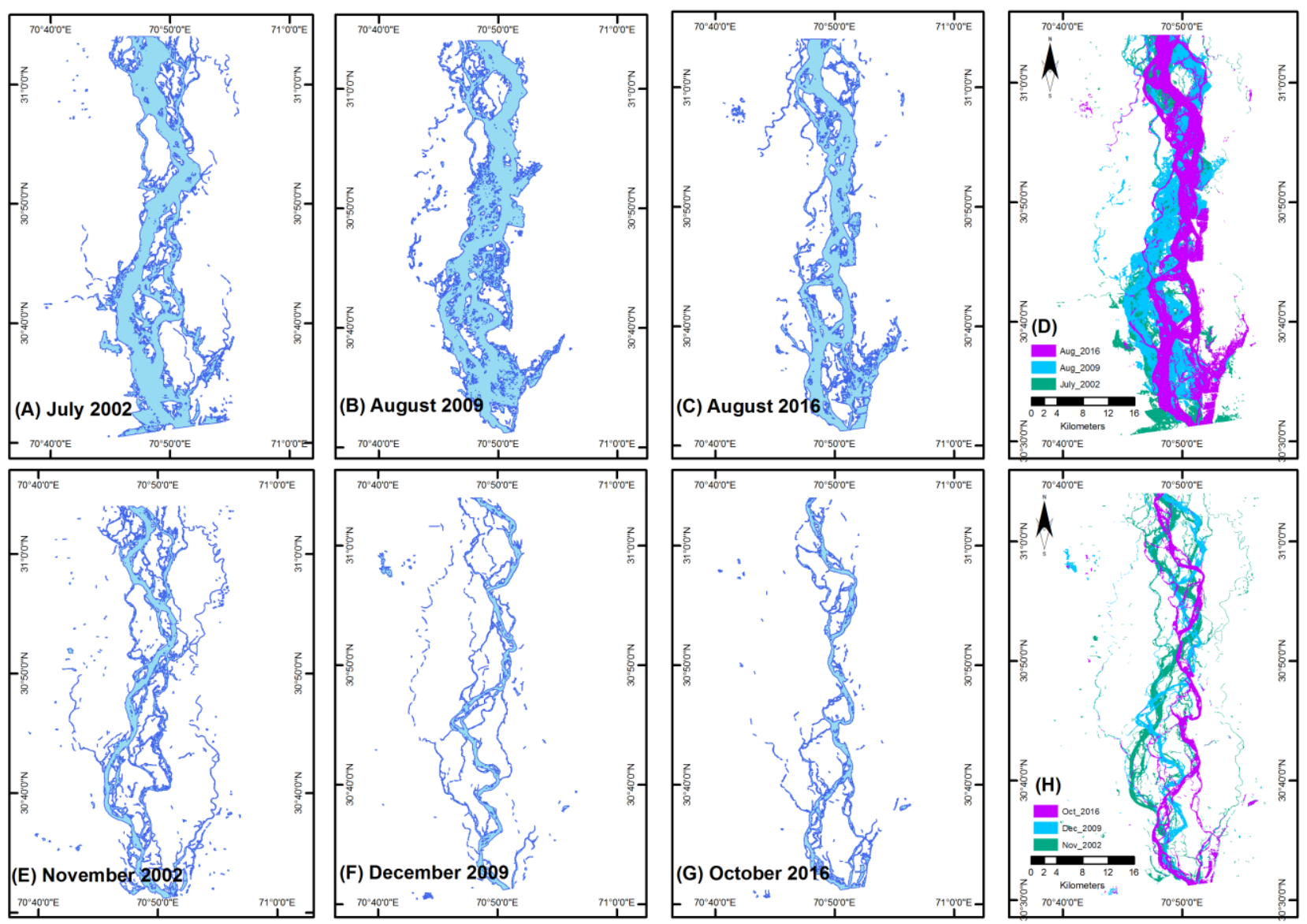

Figure 2. River path of high and low flow seasons extracted from model

From Table 2 and Table 3, data revealed that the area of around $25 \mathrm{~km}^{2}$ has been eroded from right bank, while the area of around $101 \mathrm{~km}^{2}$ eroded from left bank during 2002 to 2009 . Similarly, from 2009 to 2016, $13 \mathrm{~km}^{2}$ area eroded from right bank while $72 \mathrm{~km}^{2}$ eroded from left bank. It can be analyzed that there has been significant erosion in the left bank since 2002. However, deposition is also taking place in the vicinity but its influence is much lower than erosion. Impact of erosion is much higher in left bank of the river. Similarly, deposition is higher in right bank of the river. Figure 3 and Figure 4 shows the erosion and deposition of Indus River during 2009 and 2016. Figure 5 and Figure 6 shows graphical presentation of total erosion and deposition in various zones of study area during 2009 and 2016 respectively, in both left and right banks of Indus River. The Indus River eroded the land from zone 5 in 2009 and from zone 1 and 2 in 2016. The maximum erosion took place in zone 7 and zone 8 in left bank. While maximum deposition can be observed in zone 7 of right bank. Previous work in the area, Khan and Ali (2003) highlighted the problem of immense erosion in the vicinity but did not quantify the erosion and changes in the river bank. This study not only identifies the area vulnerable to erosion but also uses satellite remote sensing images to map eroded area and changes in the river bank since 2002.

This study also reveals the impact of embankments that were constructed to prevent area from erosion. Embankments, as seen in Figure 3 and Figure 4 are constructed along each side of river to prevent cities and agricultural lands from flood. In this study, embankments have been delineated to focus on the horizontal extent of river. The embankments were marked on high resolution Google Earth data to maintain its accuracy which then be converted into shape file and analyzed to monitor its benefit in the study area. In Layyah district, embankments along the river Indus built long time ago. These embankments were built far away from river bank, but the river now touches the embankments and already eroded the 
land left before embankments. However, embankments prevent other agricultural areas from erosion. This intrusion of river causes great burden over the embankment and its structure is now under threat. In the future, the occurrence of any major flood in the area will cause overtopping of this barrier with catastrophic consequences (Chanson, 2014).

Table 2. Total Erosion and Deposition from 2002 to 2009 in various zones

\begin{tabular}{|c|c|c|c|c|c|c|c|c|}
\hline \multirow[t]{4}{*}{ Zone } & \multicolumn{8}{|c|}{2009} \\
\hline & \multicolumn{4}{|c|}{ High Flow } & \multicolumn{4}{|c|}{ Low Flow } \\
\hline & \multicolumn{2}{|c|}{ Right Bank } & \multicolumn{2}{|c|}{ Left Bank } & \multicolumn{2}{|c|}{ Right Bank } & \multicolumn{2}{|c|}{ Left Bank } \\
\hline & $\begin{array}{l}\text { Total } \\
\text { Erosion } \\
\left(\mathrm{km}^{2}\right)\end{array}$ & $\begin{array}{c}\text { Total } \\
\text { Deposition } \\
\left(\mathrm{km}^{2}\right)\end{array}$ & $\begin{array}{l}\text { Total } \\
\text { Erosion } \\
\left(\mathrm{km}^{2}\right)\end{array}$ & $\begin{array}{c}\text { Total } \\
\text { Deposition } \\
\left(\mathrm{km}^{2}\right)\end{array}$ & $\begin{array}{l}\text { Total } \\
\text { Erosion } \\
\left(\mathrm{km}^{2}\right)\end{array}$ & $\begin{array}{c}\text { Total } \\
\text { Deposition } \\
\left(\mathrm{km}^{2}\right)\end{array}$ & $\begin{array}{l}\text { Total } \\
\text { Erosion } \\
\left(\mathrm{km}^{2}\right)\end{array}$ & $\begin{array}{c}\text { Total } \\
\text { Deposition } \\
\left(\mathrm{km}^{2}\right)\end{array}$ \\
\hline 1 & 1.13 & 12.75 & 8.10 & 5.06 & 0.72 & 5.26 & 3.63 & 8.79 \\
\hline 2 & 0.76 & 5.73 & 10.32 & 12.47 & 0.32 & 5.97 & 4.23 & 6.46 \\
\hline 3 & 0.11 & 1.06 & 7.38 & 2.77 & 0.15 & 1.18 & 3.34 & 7.95 \\
\hline 4 & 1.28 & 1.96 & 15.08 & 4.31 & 0.24 & 1.17 & 3.37 & 8.78 \\
\hline 5 & 2.94 & 0.73 & 13.17 & 1.55 & 0.60 & 2.35 & 4.01 & 7.63 \\
\hline 6 & 7.91 & 2.31 & 9.05 & 4.13 & 4.87 & 3.97 & 1.07 & 5.47 \\
\hline 7 & 6.46 & 6.16 & 7.83 & 8.59 & 1.20 & 8.27 & 4.40 & 3.29 \\
\hline 8 & 2.72 & 12.93 & 11.06 & 14.95 & 0.06 & 6.75 & 4.25 & 2.25 \\
\hline 9 & 1.01 & 8.93 & 18.04 & 2.28 & 0.00 & 1.44 & 3.81 & 6.08 \\
\hline 10 & 0.00 & 5.50 & 0.56 & 14.18 & 0.00 & 1.01 & 0.82 & 6.57 \\
\hline Total & 24.32 & 58.06 & 100.58 & 70.31 & 8.16 & 37.37 & 32.92 & 63.27 \\
\hline
\end{tabular}

Table 3. Total Erosion and Deposition from 2009 to 2016 in various zones

\begin{tabular}{|c|c|c|c|c|c|c|c|c|}
\hline \multirow[t]{4}{*}{ Zone } & \multicolumn{8}{|c|}{2016} \\
\hline & \multicolumn{4}{|c|}{ High Flow } & \multicolumn{4}{|c|}{ Low Flow } \\
\hline & \multicolumn{2}{|c|}{ Right Bank } & \multicolumn{2}{|c|}{ Left Bank } & \multicolumn{2}{|c|}{ Right Bank } & \multicolumn{2}{|c|}{ Left Bank } \\
\hline & $\begin{array}{c}\text { Total } \\
\text { Erosio } \\
n \\
\left(\mathrm{~km}^{2}\right)\end{array}$ & $\begin{array}{c}\text { Total } \\
\text { Deposition } \\
\left(\mathrm{km}^{2}\right)\end{array}$ & $\begin{array}{c}\text { Total } \\
\text { Erosion } \\
\left(\mathrm{km}^{2}\right)\end{array}$ & $\begin{array}{c}\text { Total } \\
\text { Deposition } \\
\left(\mathrm{km}^{2}\right)\end{array}$ & $\begin{array}{l}\text { Total } \\
\text { Erosion } \\
\left(\mathrm{km}^{2}\right)\end{array}$ & $\begin{array}{c}\text { Total } \\
\text { Deposition } \\
\left(\mathrm{km}^{2}\right)\end{array}$ & $\begin{array}{l}\text { Total } \\
\text { Erosion } \\
\left(\mathrm{km}^{2}\right)\end{array}$ & $\begin{array}{c}\text { Total } \\
\text { Deposition } \\
\left(\mathrm{km}^{2}\right)\end{array}$ \\
\hline 1 & 5.59 & 4.12 & 2.20 & 12.64 & 3.08 & 0.72 & 1.67 & 6.58 \\
\hline 2 & 3.61 & 3.04 & 8.31 & 8.64 & 1.23 & 1.13 & 5.93 & 4.77 \\
\hline 3 & 0.55 & 1.16 & 6.90 & 5.28 & 0.13 & 0.25 & 6.38 & 5.43 \\
\hline 4 & 0.06 & 2.61 & 1.08 & 18.11 & 0.00 & 0.35 & 4.40 & 5.38 \\
\hline 5 & 0.29 & 5.78 & 4.44 & 15.92 & 0.00 & 0.99 & 4.37 & 4.95 \\
\hline 6 & 0.29 & 15.20 & 9.43 & 8.14 & 0.05 & 6.88 & 6.66 & 1.33 \\
\hline 7 & 1.19 & 19.62 & 6.58 & 8.77 & 1.43 & 2.06 & 5.40 & 4.85 \\
\hline 8 & 0.62 & 13.61 & 18.04 & 6.80 & 0.66 & 1.40 & 7.39 & 4.53 \\
\hline 9 & 0.29 & 5.20 & 6.52 & 16.33 & 1.76 & 0.00 & 5.39 & 5.62 \\
\hline 10 & 0.00 & 0.00 & 8.38 & 2.73 & 0.00 & 0.00 & 5.86 & 1.87 \\
\hline Total & 12.49 & 70.34 & 71.89 & 103.36 & 8.34 & 13.78 & 53.44 & 45.31 \\
\hline
\end{tabular}



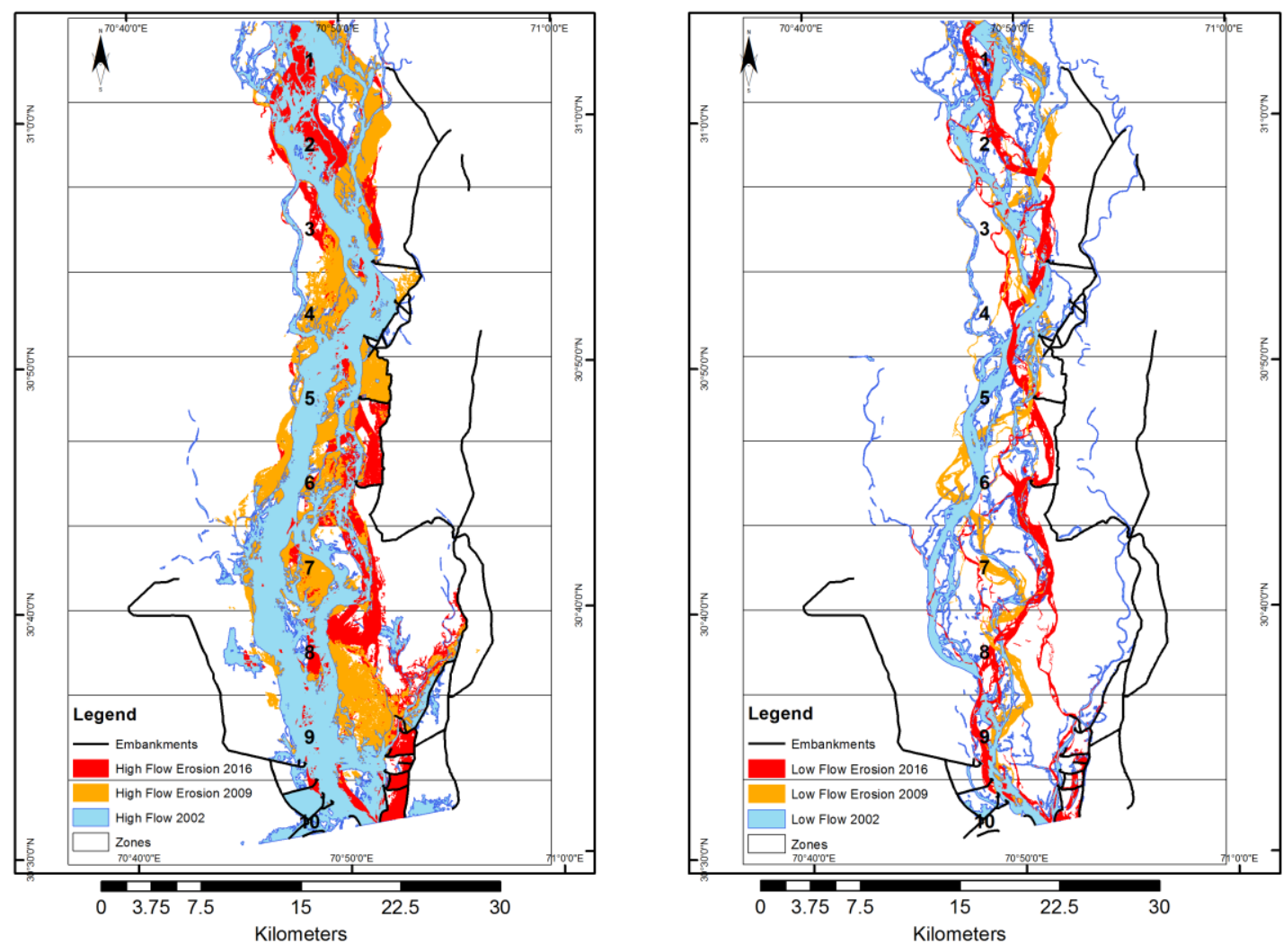

Figure 3. River bank erosion in 2009 and 2016
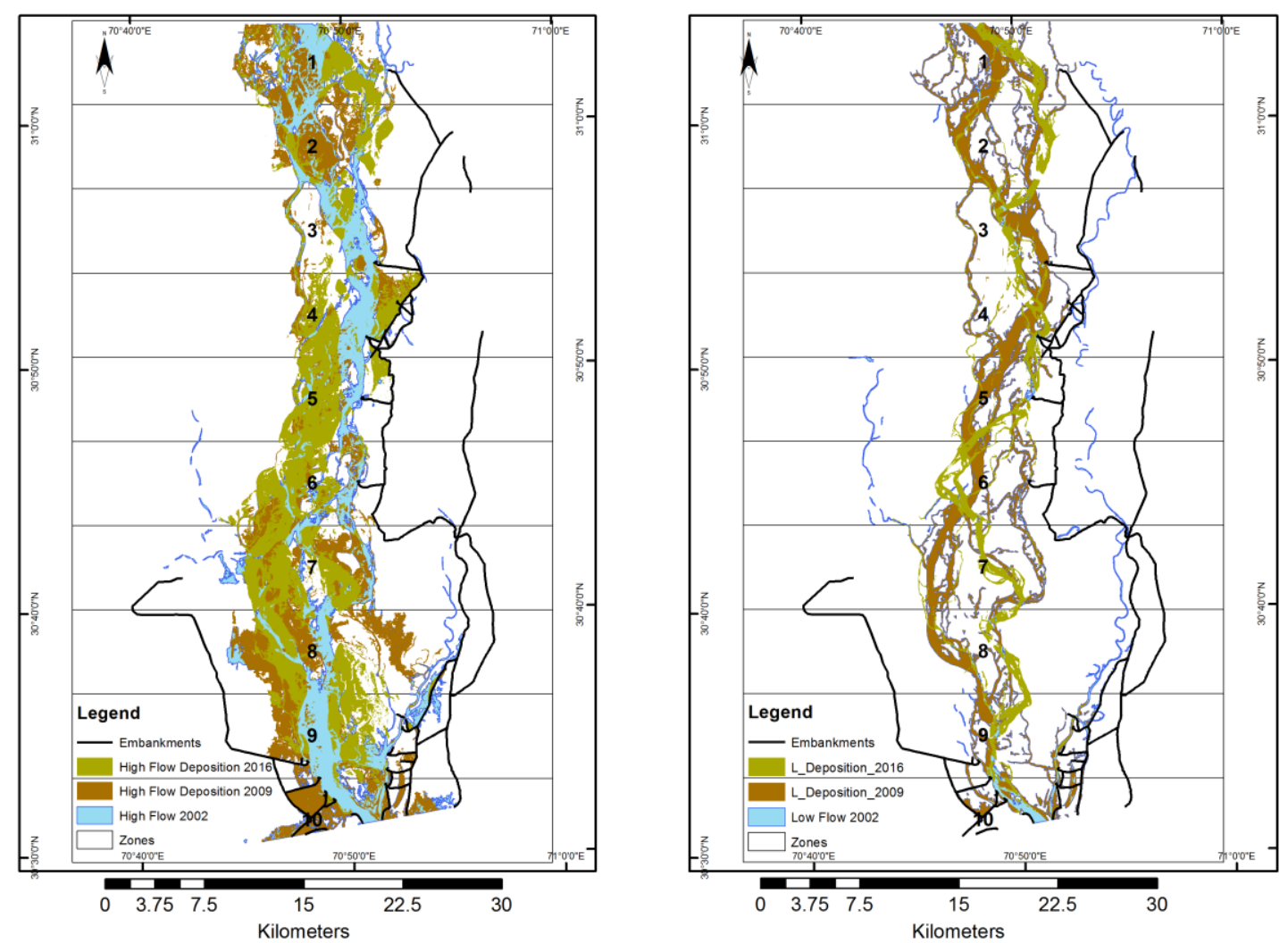

Figure 4. River deposition in 2009 and 2016 
High Flow Erosion in 2009 \& 2016

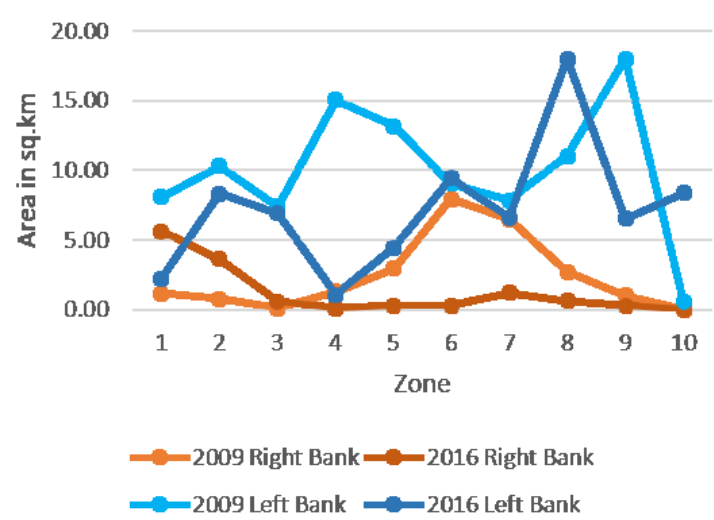

Low Flow Erosion in 2009 \& 2016

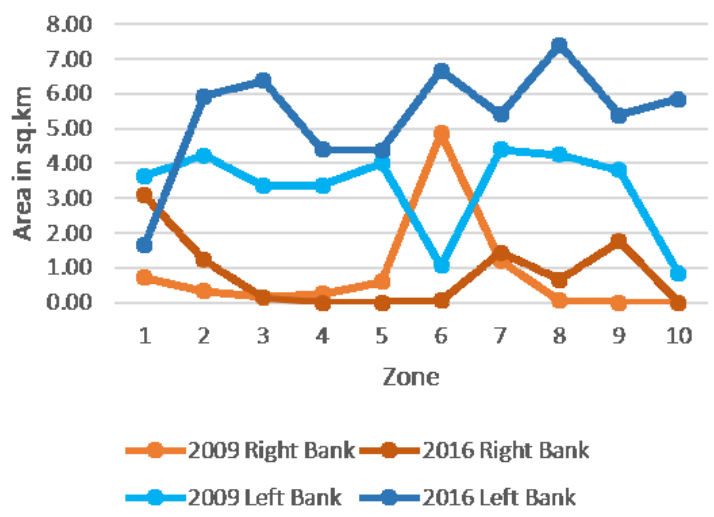

Figure 5. Intensity of Erosion in various zones during 2009 and 2016 in high and low flow seasons
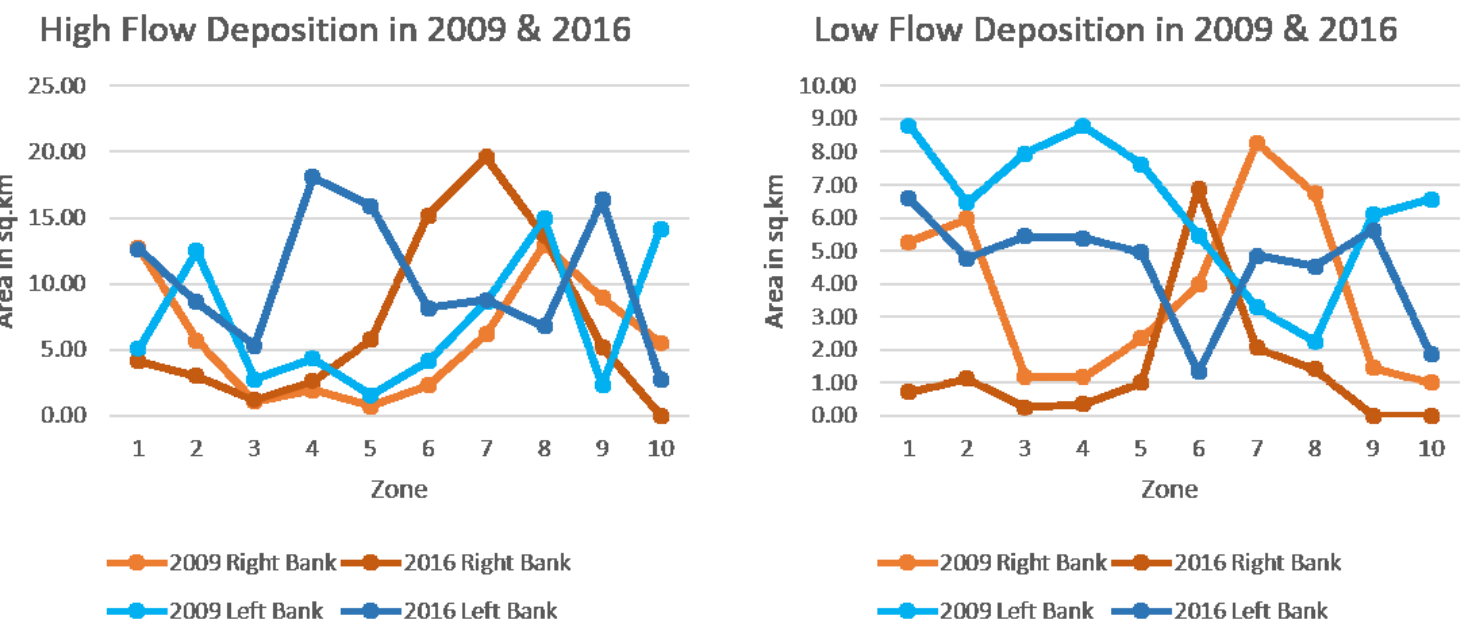

Figure 6. Intensity of Deposition in various zones during 2009 and 2016 in high and low flow seasons

\section{CONCLUSION}

The current study used remote sensing images to identify river erosion zones along the Indus River particularly along Layyah and Muzaffargarh Districts from 2002 to 2016. It can be certainly expressed that GIS can be an extremely productive apparatus during the time spent distinguishing proof and mapping of river changes and bank erosion. Indus River is very dynamic in nature that continuously shifts its paths over certain time period. This study highlighted the areas which are vulnerable to erosion. Study showed that the Indus River is continuously engulfing the land on the left bank of study area. The area of around 101 $\mathrm{km}^{2}$ has been eroded during 2002 to 2009 and around $72 \mathrm{~km}^{2}$ during 2009 to 2016 . This gives the rate of erosion in this area around $11.5 \mathrm{~km}^{2}$ per year. It has been observed that the river is shifting more towards its left bank. Erosion was significantly high in left bank of the river causing damage to the agricultural land and a threat to life of people raised there and their settlements and infrastructure.

To protect the land and agriculture, embankments were built in the vicinity by the concerned authorities, maintaining a good distance from the river bank. However, with the passage of time the land is almost eroded and currently the river is touching the embankments in various zones. Similarly, deposition is high in the right bank of the river which in some places, now developed and is used for agricultural practices. Areas with high erosion must be prioritized and steps should be taken to protect the land. This creates needs to comprehensively study the land, particularly the geology of the area and its tectonics in 
conjunction with flow regime in the area. This is to understand and predict more complex processes and suggesting practical results to be applied by the management authorities. Results generated in this study when combined with other in situ data sets, such as topography, soil type, vegetation type and cover, and conservation practices in the area, will serve toward taking practical measures to protect the land and life of the people not only in Layyah district but along the whole Indus River, ifthe method applied to other areas along the river.

\section{REFERENCES}

Ali, K. F., \& De Boer, D. H. (2010). Spatially distributed erosion and sediment yield modeling in the upper Indus River basin. Water Resources Research, 46(8), 1-16. [Crossref]

Chanson, H. (2014). Embankment overtopping protection systems. Acta Geotechnica, 10(3), 305-318. [Crossref]

Clift, P. D. (2002). A brief history of the Indus River. Geological Society, London, Special Publications, 195(1), 237-258. [Crossref]

Florsheim, J. L., Mount, J. F., \& Chin, A. (2008). Bank Erosion as a Desirable Attribute of Rivers. BioScience, 58(6), 519. [Crossref]

Fuller, I. C., Large, A. R. G., \& Milan, D. J. (2003). Quantifying channel development and sediment transfer following chute cutoff in a wandering gravel-bed river. Geomorphology, 54(3), 307-323. [Crossref]

Khan, A. A., \& Ali, S. B. (2003). Effects of erosion on Indus River bio-diversity in Pakistan. Pakistan Journal of Biological Sciences, 6(12), 1035-1040. [Crossref]

Khan, B., Iqbal, M. J., \& Yosufzai, M. A. K. (2011). Flood risk assessment of river Indus of Pakistan. Arabian Journal of Geosciences, 4(1-2), 115-122. [Crossref]

Kotoky, P., Bezbaruah, D., Baruah, J., \& Sarma, J. N. (2005). Nature of bank erosion along the Brahmaputra river channel, Assam, India. Current Science, 88(4), 634-640.

Kummu, M., Lu, X. X., Rasphone, A., Sarkkula, J., \& Koponen, J. (2008). Riverbank changes along the Mekong River: Remote sensing detection in the Vientiane-Nong Khai area. Quaternary International, 186(1), 100-112. [Crossref]

Lawler, D. M. (1993). The measurement of river bank erosion and lateral channel change: A review. Earth Surface Processes and Landforms, 18(9), 777-821. [Crossref]

Li, L., Lu, X., \& Chen, Z. (2007). River channel change during the last 50 years in the middle Yangtze River, the Jianli reach. Geomorphology, 85(3), 185-196. [Crossref]

McFeeters, S. K. (1996). The use of the Normalized Difference Water Index (NDWI) in the delineation of open water features. International Journal of Remote Sensing, 17(7), 1425-1432. [Crossref]

Muller, E., Decamps, H., \& Dobson, M. K. (1993). Contribution of Space Remote-Sensing To River Studies. Freshwater Biology, 29(2), 301-312. [Crossref]

Pati, J. K., Lal, J., Prakash, K., \& Bhusan, R. (2008). Spatio-temporal shift of western bank of the Ganga River, Allahabad city and its implications. Journal of the Indian Society of Remote Sensing, 36(3), 289-297. [Crossref]

Rinaldi, M. (2003). Recent channel adjustments in alluvial rivers of Tuscany, central Italy. Earth Surface Processes and Landforms, 28(6), 587-608. [Crossref]

Sarkar, A. (2012). RS-GIS Based Assessment of River Dynamics of Brahmaputra River in India. Journal of Water Resource and Protection, 4(2), 63-72. [Crossref]

Searle, M. P., \& Owen, L. A. (1999). Indus River: Biodiversity, Resources, Humankind. In P. S. Meadows \& A. Meadows (Eds.), the environmental impact of the River Indus on the coastal and offshore zones of the Arabian Sea and the North-West Indian Ocean (pp. 210-230). Karachi: Oxford University Press, Karachi, Pakistan.

Surian, N. (1999). Channel changes due to river regulation: the case of the Piave River, Italy. Earth Surface Processes and Landforms, 24(12), 1135-1151. [Crossref]

Thakur, P. K., Laha, C., \& Aggarwal, S. P. (2012). River bank erosion hazard study of river Ganga, upstream of Farakka barrage using remote sensing and GIS. Natural Hazards, 61(3), 967-987. [Crossref]

Winterbottom, S. J., \& Gilvear, D. J. (2000). A GIS-based approach to mapping probabilities of river bank erosion: regulated River Tummel, Scotland. Regulated Rivers: Research \& Management, 16(2), 127140. [Crossref]

Wolpert, S. A. (1999). India. University of California Press. [Googlebook] 
Yang, X. (1996). Satellite Monitoring of the Dynamic Environmental Change of the Active Yellow River Delta, China. International Archives of Photogrammetry and Remote Sensing, 31, 801-806.

Yang, X., Damen, M. C., \& van Zuidam, R. A. (1999). Satellite remote sensing and GIS for the analysis of channel migration changes in the active Yellow River Delta, China. International Journal of Applied Earth Observation and Geoinformation, 1(2), 146-157. [Crossref] 